ISSN 2076-0752

www.mdpi.com/journal/arts

Article

\title{
Toward an A Priori Sustainable Architecture
}

\section{Nicola Scardigno}

Polithecnic of Bari, Department of Science and Civil Engineer, Via Edoardo Orabona 4, Bari, 70126, Italy; E-Mail: nickscardigno@yahoo.it; Tel.: +39-347-0928052

Received: 27 October 2013; in revised form: 2 December 2013 / Accepted: 17 December 2013 / Published: 3 January 2014

\begin{abstract}
After decades of belief in the principles that man has absolute dominion over nature, and thus, in the separation of natural and anthropic processes, humanity is at the beginning of a new era characterized by the search for a renewed pact between man and the environment. This search has yielded new terminology to indicate sustainable ways of transforming the anthropic environment: zero-energy development, bioclimatic architecture, eco-buildings and low carbon footprint. Apparently, this new linguistic phenomenon is symptomatic of two trends: firstly, of a sort of amnesia, in the sense that traditional architecture was already sustainable, not out of choice, but out of survival needs (via its ties to local climate and materials); and secondly, of an identity crisis among designers caused by the difficulty in finding specific boundaries for the discipline of architecture and urban design. Reflecting on these aspects and through the description of two recent projects, this article addresses the renewed interest in re-establishing an inseparable relationship between natural and anthropic processes. The goal is to elucidate a localized form of sustainability by recovering and upgrading traditional knowledge.
\end{abstract}

Keywords: localized sustainability; bioclimatic architecture; eco-buildings; eco-developments; constructive techniques; typology; traditional knowledge

\section{Introduction}

Any evaluation of environmental sustainability should be based on how the environment tends to absorb the result of an anthropic intervention. The Italian architect, Gianfranco Caniggia, uses the concept of "yield" to translate the dialectic between human action and environmental reaction [1]. This concept is inversely proportional to the time necessary for anthropic structures to take to adapt within 
an already existing environmental configuration. Therefore, we should have: high yield, in the case of minor adaptations of time, and lower yield, in the case of longer adaptions of time or non-adaptation. Today, the concept of yield is synonymous with "ecological footprint". Regarding this concept, the Italian architect, Alberto Magnaghi, says it can be reduced by: "providing local closed cycles of action (water, waste, food, energy, etc.); limiting movement of people and goods; improving product quality and uniqueness (food, environment and culture); restoring and regenerating environmental system structure and function, as well as ensuring their self-reproduction; and regenerating agricultural and forestry activities as main producers of public goods" [2]. All these needs are contained within the book entitled "The Local Project". Today, there are still professionals who believe environmental-sustainability practices must be contextualized. In other words, although concepts, like zero-energy development, bioclimatic architecture, eco-building and low carbon footprint, reflect global awareness that man and nature must find a renewed balance, all these terms need to be translated into localized action. Unfortunately, this rarely happens. In fact, looking at most current building production, it seems this new linguistic trend, in tandem with an eye toward the equally trendy and generic concept of sustainability, tends to prefigure architectures only on the basis of energetic performances obtained through forms of applied technology (conceived almost as imperative need).

\section{A Posteriori Sustainability vs. A Priori Sustainability}

Most of the recent literature on sustainable design tends to evaluate architecture on the basis of energetic performances expressed by numerical data, while ignoring the idea that architecture, as a synthesis of civil processes, is an expression of constructive techniques and typological transformations developed throughout history.

For example, two of the most recent eco-neighborhoods, such as the BedZED (2002) in London, UK and the Vauban in Freiburg, German (2006), reflect the anomalous idea of architecture that strives to optimize energetic performance [3]. On the one hand, it is true that these neighborhoodssometimes called "zero energy developments"-represent urban systems that are energetically independent of fossil fuels, but on the other hand, they embody two dramas within our architectural panorama: the "generic" and the "ephemeral". The former, in the wake of the "generic city" concept [4], is indicative of architecture that is not able to reflect local character, because it is rooted in a paradigm of global self-identification, whereas the cult of the ephemeral, conceived of as an alternative solution to the dearth of long-term projects, is represented by settlements and constructive choices marked by an innately temporary nature. A wicked form of prefabrication encouraged these two streams and consequently promoted a new era of "placeless" and disposable architecture.

At the same time, the idea of eco-sustainability, represented by practices of "urban greening", is another facet of media jargon. In fact, the idea that nature can camouflage architecture represents new ideological frontiers in "experimental urban aesthetics" [5]. This phenomenon and the increasingly frequent practice of "vertical farms" and "towers of flowers" would seem to orient toward a model of a vertical garden city (i.e., cities and architectures inspired by a myth of eternal youth, where the idea of an evergreen architecture pretends to replace the innate "material character" of structures, both urban and architectural.). Why is there such a claim? 
Based on the claims above, this article will outline another model of environmental sustainability; perhaps with a lesser media impact than an avant-garde "liquid" sustainability [6], but certainly a model aiming to preserve, through dutiful upgrading, the language and identity of place. In other words, this article will go beyond linguistic phenomena and, thus, beyond a more or less generalized modus operandi that is driving the inability to recognize a formal link between building products and environments and, so, to the loosening of what the Italian architect, Rosario Giuffrè, calls "magistero esperenziale" (i.e., the accumulation of years of constructive experience) [7-8]. Ultimately, the intention here is to re-evaluate the very concept of sustainability within the design process. First, let us consider two schemes:

The first scheme reflects most contemporary attitudes that consider sustainability as a sort of stereotyped discipline on which the entire design process (idea-project-construction) converges. It can be considered a sort of a posteriori sustainability, materialized through standardized ideologies and technologies and just able to produce buildings in the form of universal statutes that are highly susceptible to stylistic experimental changes, usually developed on a global scale. Conversely, the second scheme shows an a priori concept of sustainability. Here, the three design phases are already conceived of in a sustainable way from the beginning, because they are referred to as "cultural areas" (i.e., territory that is naturally bounded thanks to specific behaviors, customs and language stratified throughout history). Therefore, the second scheme is representative of an adaptable sustainability, where both typo-morphological and technological choices evolve, in the form of upgrading, from an inherited technical-constructive knowledge. Such an idea of "adaptive sustainability" allows one to enhance a designer's critical-interpretative skills and, so, to develop building production characterized by a multiplicity of alternatives. In other words, the idea of sustainable research aimed to obtain energetic performances through generalized and ahistorical architectural solutions (Figure 1) contrasts with the complex task of experimenting with the practice of sustainable design by considering notions of "time" and "place" (Figure 2). The notions of time and place are embodied in the concept of type: a concept that does not correspond to an architectural solution established a posteriori mostly endowed with acrobatic sustainable devices, but rather, an a priori idea of architecture (i.e., a body of customs and norms acquired over the course of building within a specific geographical context). This idea represents the framework for previewing a proposed building, as well as the substrate upon which research of sustainable strategies should be based.

Figure 1. An a posteriori conception of sustainability.

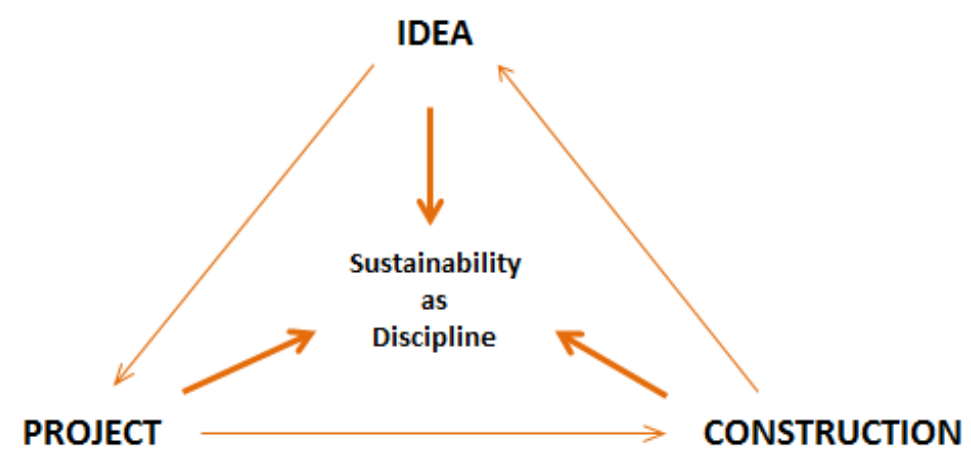


Figure 2. An a priori conception of sustainability.

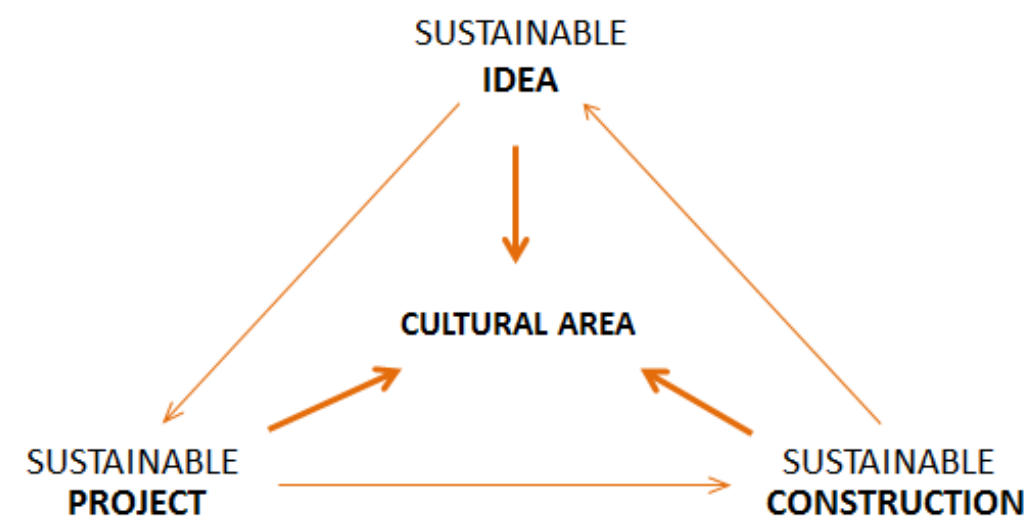

\section{Two Cases of $\boldsymbol{A}$ Priori Sustainability}

Now, referring to the concept of a priori sustainability, this article will describe two recent projects: a bioclimatic house designed and realized by a young Syrian architect in a rural area south of Damascus and a project of urban regeneration of the Egyptian Siwa Oasis developed within a thesis work at Bari Polytechnic, Faculty of Architecture.

A bioclimatic house was built in Dier El-Boukhet (Dara province), Syria, in 2011. Interestingly, during a recent lecture at The Prince's School of Traditional Arts in London, the Syrian architect, M. Hosam Jiroudy, started to describe his project, not talking about design principles or ideological preconceptions, but referring to the natural building materials that Syria offers: lime stone in the north; coral stone in the coastal areas; sand stone in the central province; lava stone in the south; and clay from which mud and bricks can be produced, in the east. In addition, he referred to traditions and crafts, such as stone masonry and woodwork, in the site climatic analysis and to the typological studies of traditional Damascus courtyard houses (Figure 3). All aspects of the second scheme above (Figure 2) are represented (i.e., the phases of the idea, which is a cognitive step that corresponds to the "quantities" and "qualities" concerning the entire design process). Both qualitative and quantitative data are deduced from the "cultural area" characterized by materials, climate and building typology connoting the area south of Damascus. On the basis of these features, the Syrian architect made his choices and considered the following design phases: project and construction (Figures 4-6). Within these two phases, Hosam made compositional, technological and constructive evaluations, all inextricably linked to each other. This is proven by elements that contributed to develop the house's interior natural microclimate. For example, the house's orientation and the double-courtyard system around which the house's spaces are arranged, the thermal and moisture resistance of the natural lava stone transformed into basalt solid block used for the walls and the construction techniques adopted for the two dome types (one pressed dome built on the bathub and a high dome on muqarnas built on top of the main $Q u^{\prime} a$ ), both with multiple circular openings covered by small blown glass domes in order to reduce the internal temperature according to the principal of dew condensation.

In conclusion, the rural house designed by Hosam demonstrates that the search for sustainability in architecture can represent a real opportunity to upgrade construction techniques and technologies by maintaining a strong link with a place's culture. Furthermore, it represents an example of bioclimatic architecture that has significantly reduced building costs: there are no imported materials, no applied 
technological apparatus (because it is integrated and belongs to the architecture itself) and no use of foreign labor.

Figure 3. Traditional Syrian courtyard typologies (drawings courtesy of M. Hosam Jiroudy, Architect).
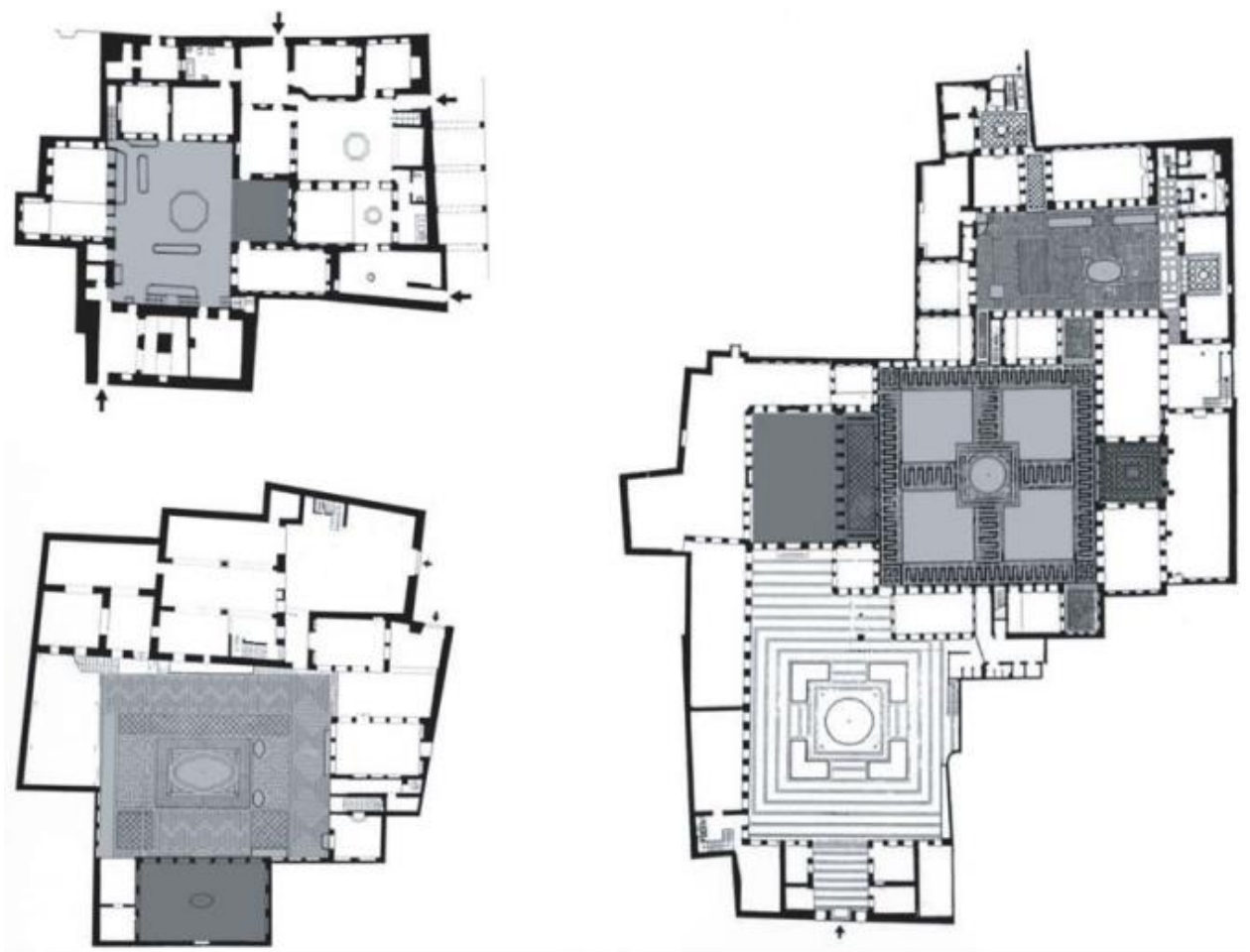

Figure 4. House plan (drawings courtesy of M. Hosam Jiroudy, Architect).

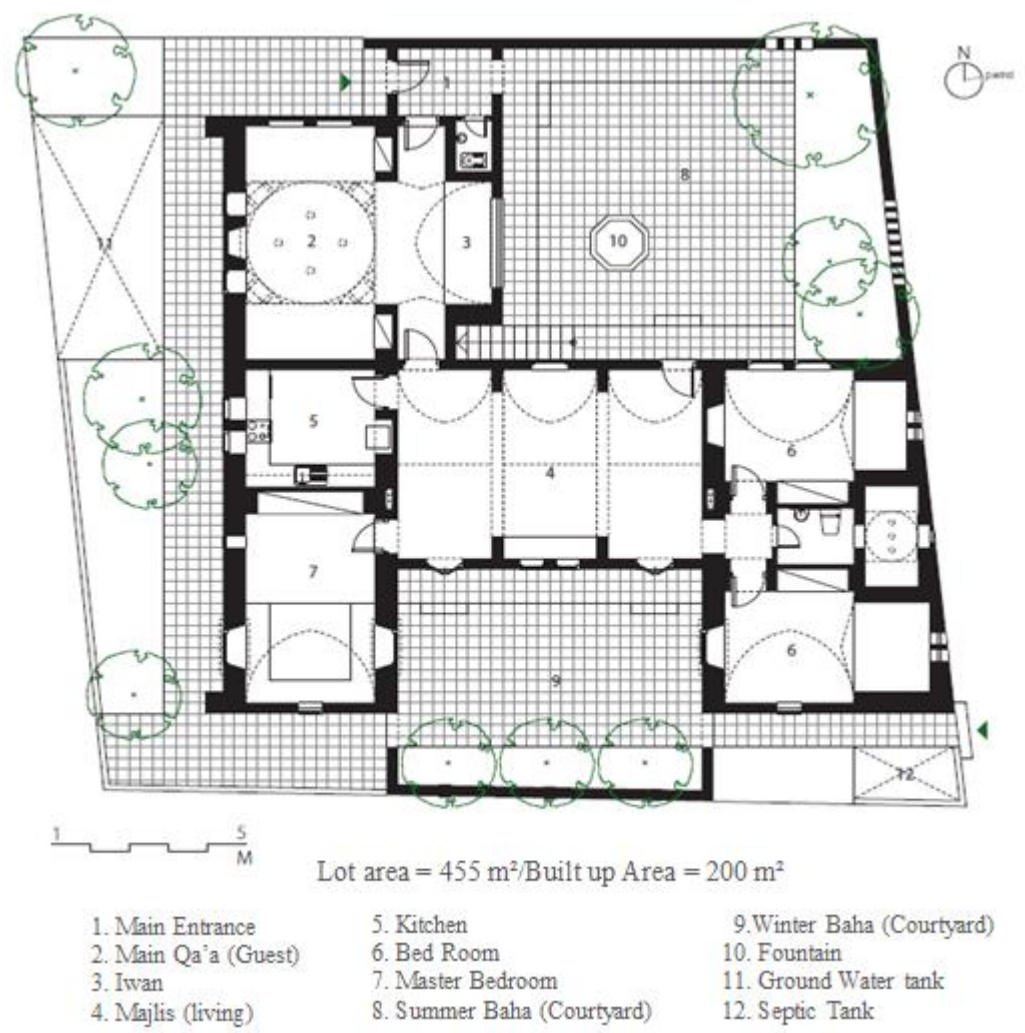


Figure 5. Construction phases (images courtesy of M. Hosam Jiroudy, Architect).
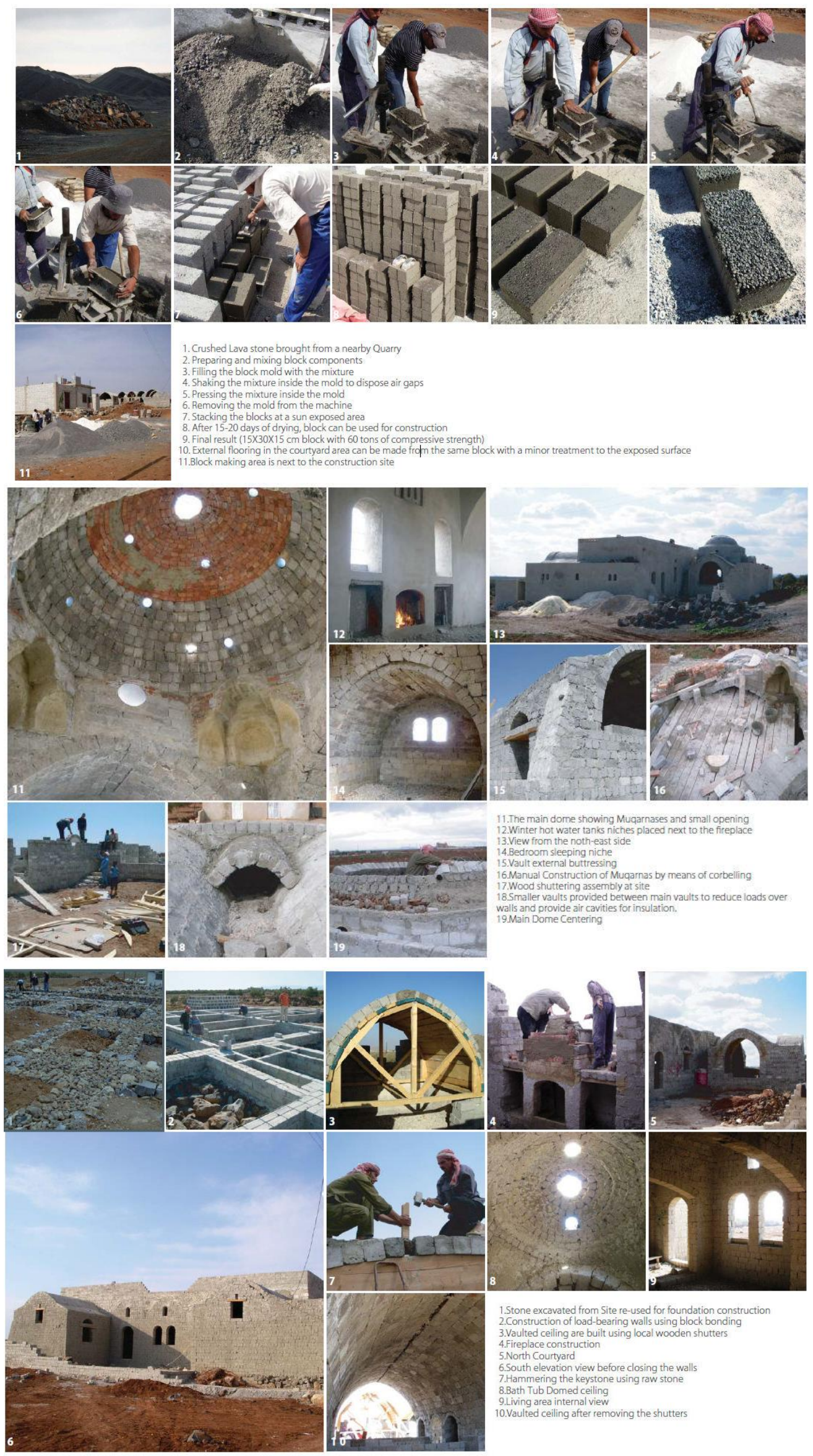
Figure 6. House finished (images courtesy of M. Hosam Jiroudy, Architect).

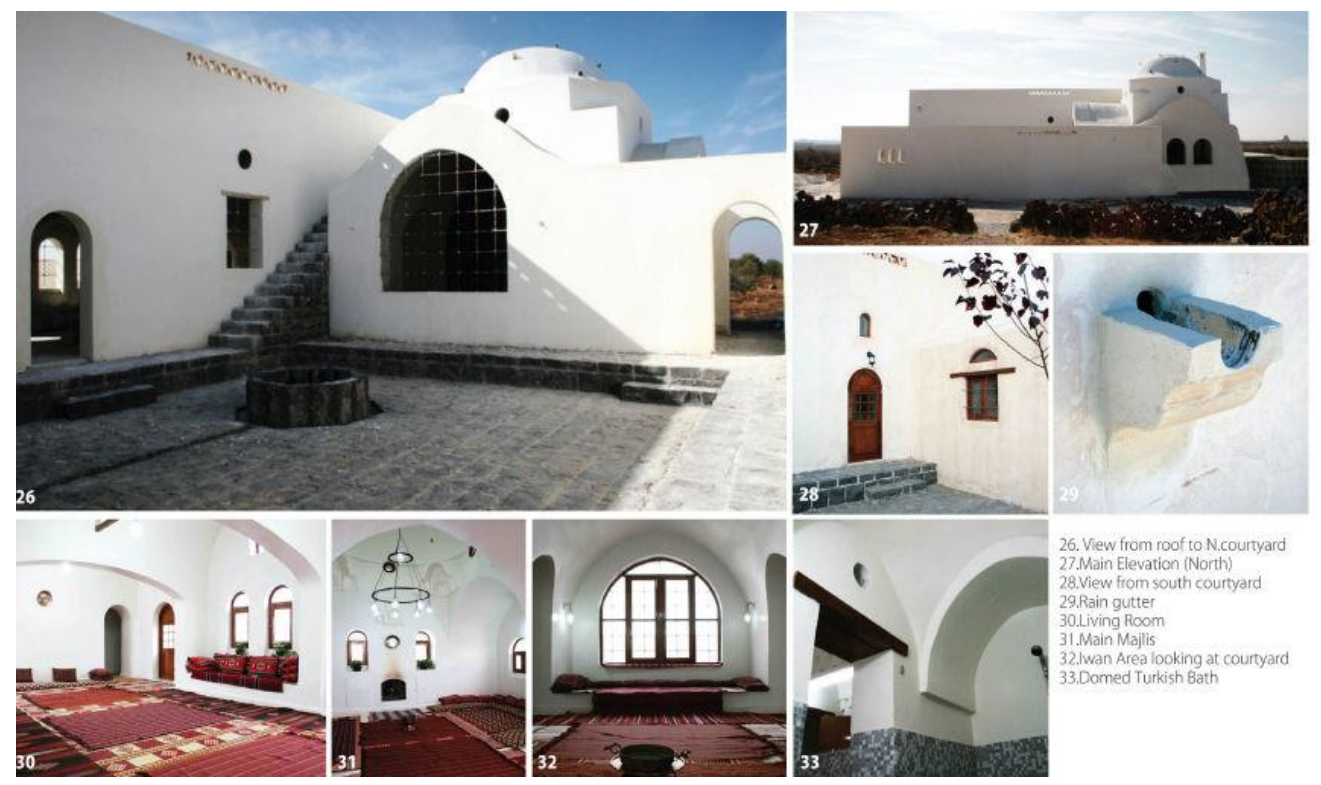

Figure 7. The plan that indicates the design areas within Siwa Oasis, Egypt (drawings courtesy of the following authors: Calvano S., Loconte P., Pizzolante S., Ricupero P. and Vitulli A.).

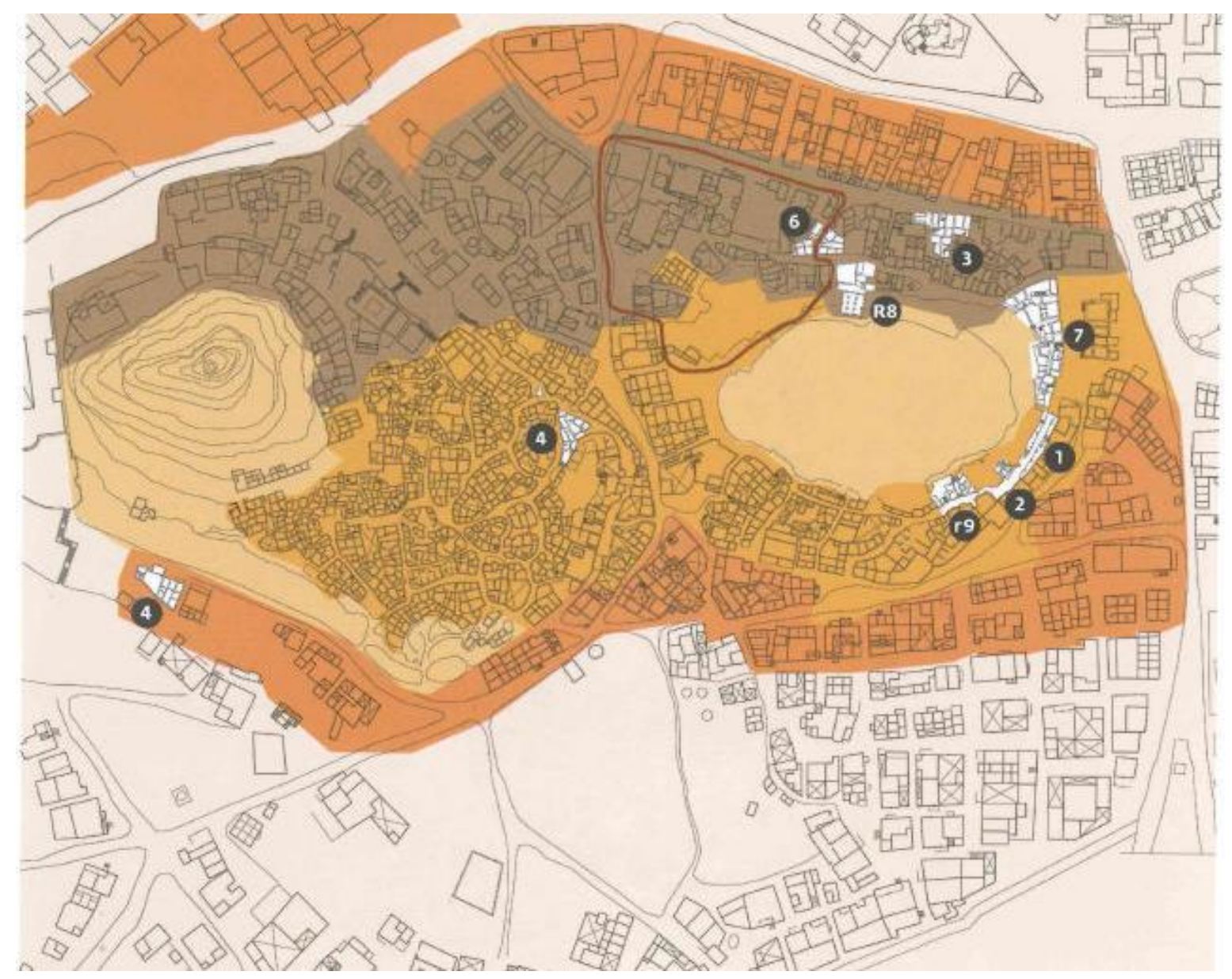


Figure 8. Typological studies on the Siwa Oasis (drawings courtesy of the following authors: Calvano S., Loconte P., Pizzolante S., Ricupero P. and Vitulli A.).
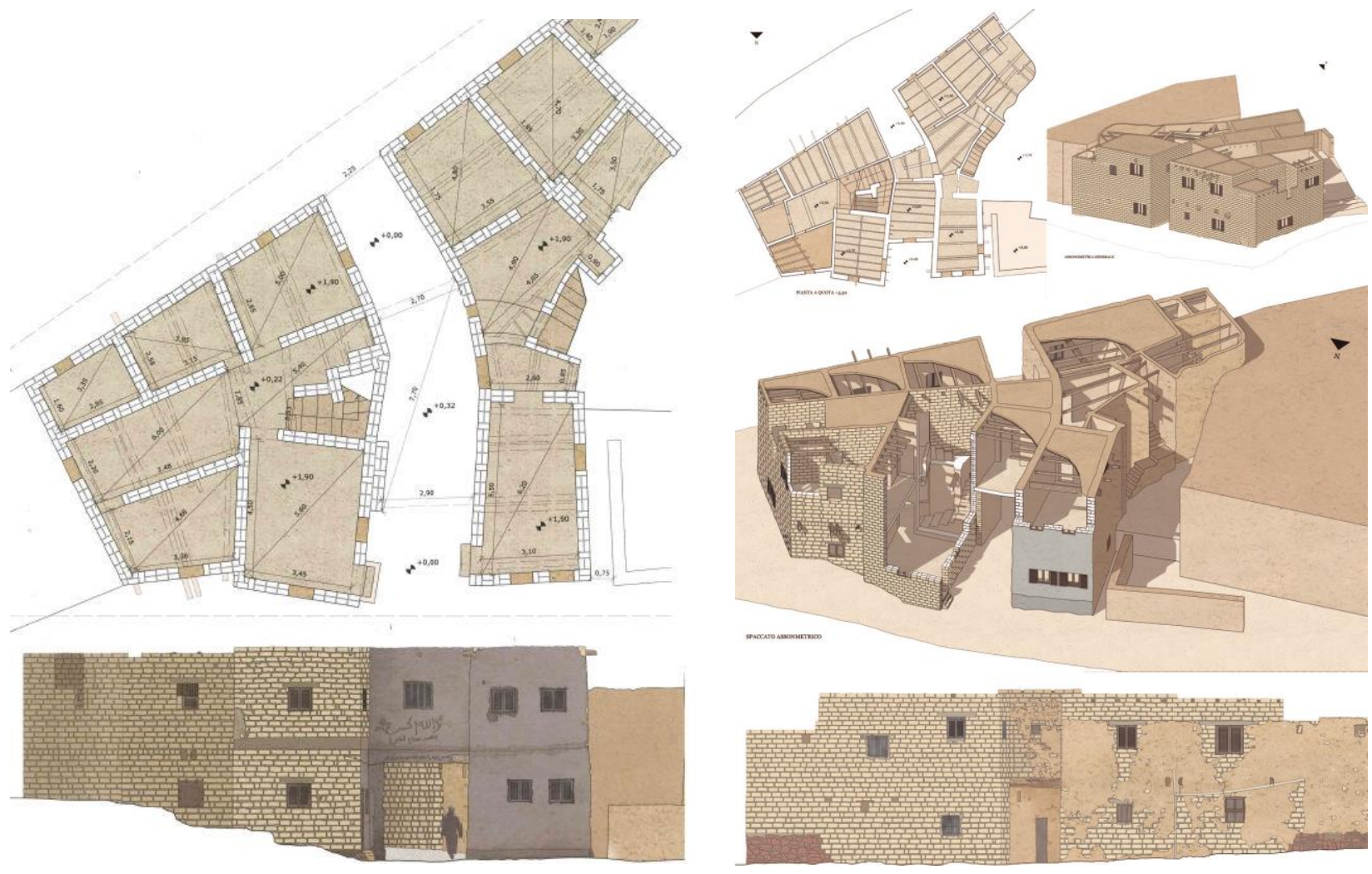

Figure 9. Example of the "mending" urban project within the Siwa Oasis (drawings courtesy of the following authors: Calvano S., Loconte P., Pizzolante S., Ricupero P. and Vitulli A.).

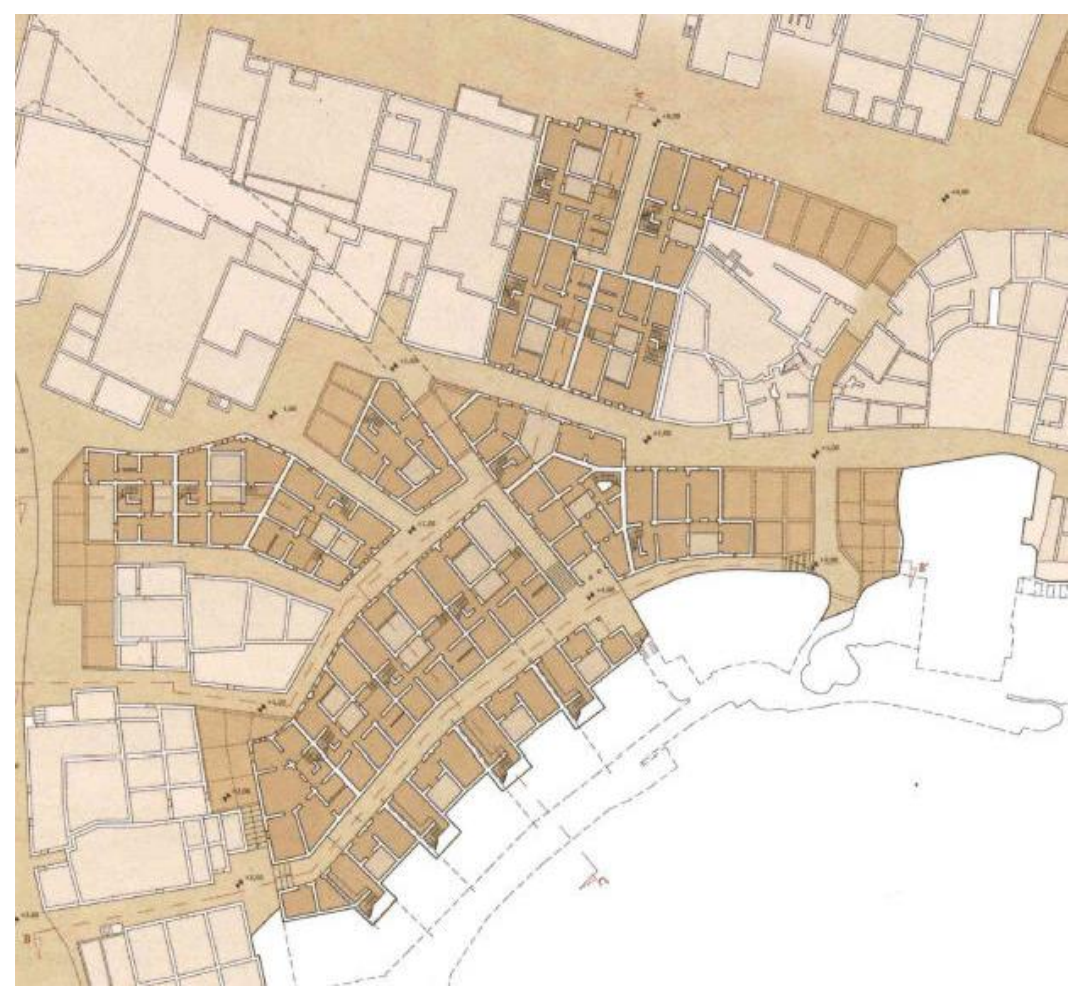


Figure 10. Studies of the construction techniques adopted within the Siwa Oasis (drawings courtesy of the following authors: Calvano S., Loconte P., Pizzolante S., Ricupero P. and Vitulli A.).

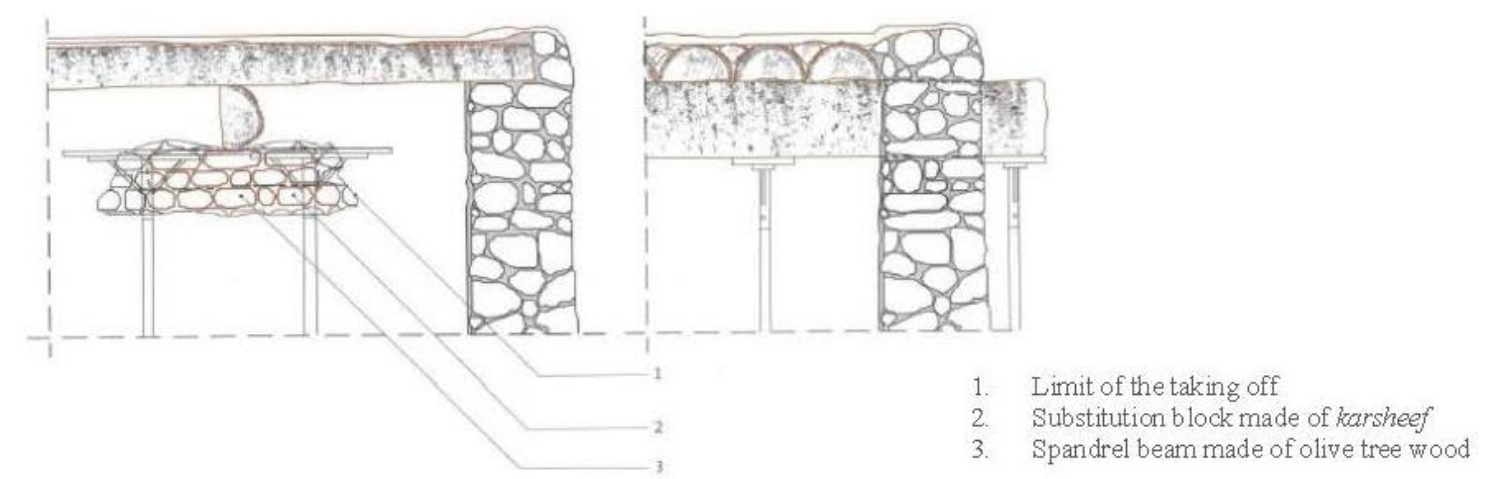

S.02 sostituzione orizzontamenti

S.02 ceilings replacement
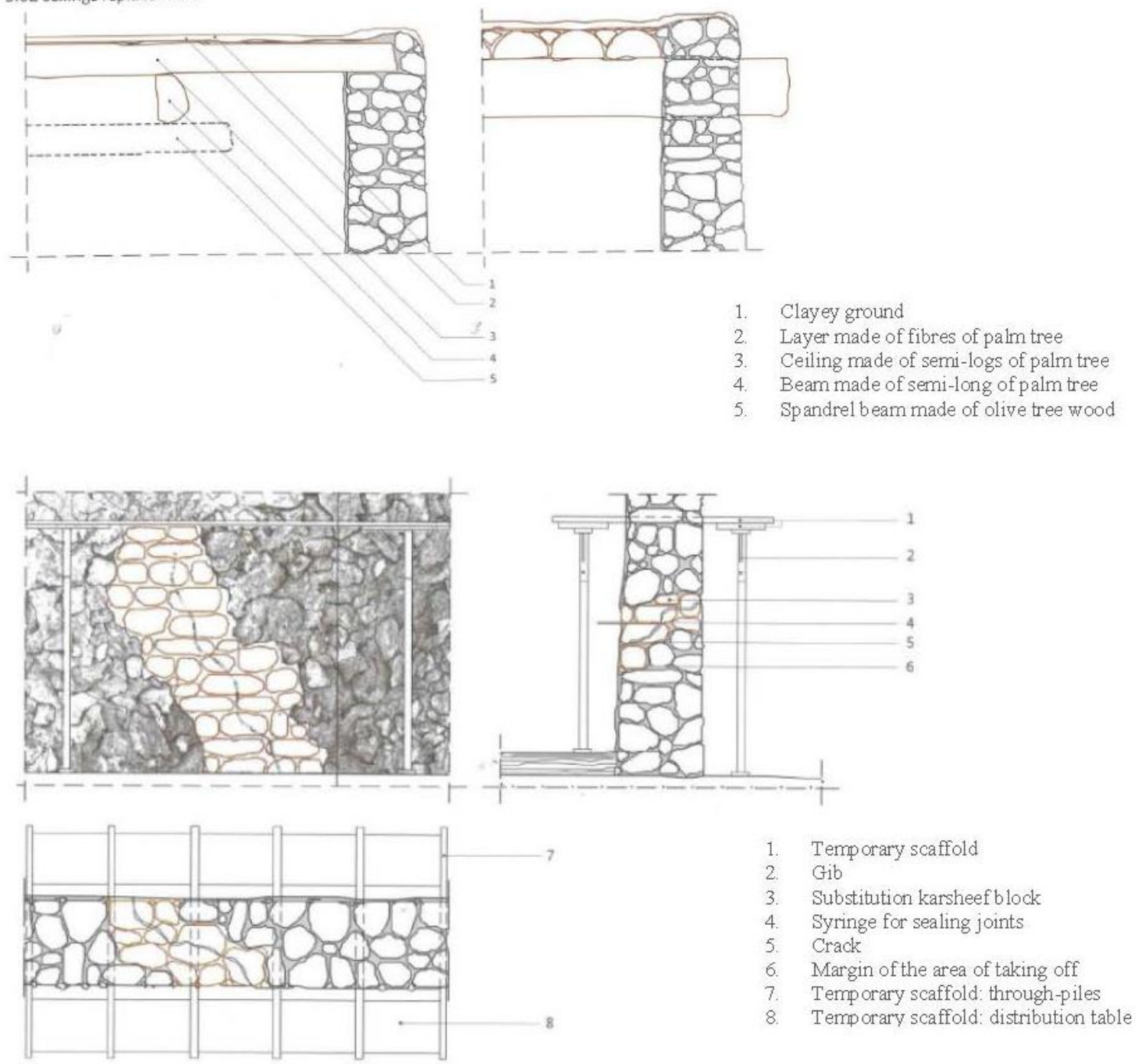

Regarding the urban regeneration project in the Siwa Oasis, Egypt (2009), there are two essential issues to consider: the first is synthesized by Attilio Petruccioli's quote: "...whereas in other geographical contexts, sustainability is an aspiration, in the Oasis it is essential to survive" [9], which means that the idea of sustainability is part of the region's DNA; the second is based on the 
consolidated relationship of "men to soil" as the result of a stratified, continuous process. Both of these issues led the design team to develop a project inspired by a detailed analysis of the site: a way to develop a project with a high level of "yield". In particular, the design team analyzed the landscape of Siwa Oasis as an urbanized territory in order to understand the project from a morphological point of view (i.e., according to geological, topographical, orographic and hydrographic evaluations). Considering the fact that the entire settlement consists of two main residential areas, Shali and Adrar, a "diachronic reading" of its fabric was developed: from the fortified village (ksar) of Shali, to its expansion and duplication on the hill of Adrar and, at last, to the fusion of the two centers. After that, thanks to an analytical survey, the designers had the opportunity to graphically re-build Siwa's urban fabric, from its formative phase to its more recent transformations.

Essentially, the analytical phase represents the corpus of knowledge (the idea phase, Figure 2) that informs the entire project phase. In this case, the project concerned re-construction and restoration. Specifically, as an urban project, the designers tried to "mend" (ricucire) an urban area that had lost its architectural and landscape identity by reassembling part of the fabric (Figure 7). The study of the typological process played a key role in this mending; by understanding the typo-morphological evolution of houses and public buildings, designers are able to recognize the stages of evolution of the entire fabric throughout history (Figures 8,9). Instead, the reconstruction and restoration project was inspired by a conservative philosophy that reflected a process of "using-maintaining-adjusting" the built environment that is typical of this area. By studying how materials and constructive techniques were historically used within a geographical context (Figure 10), designers experimented with a way to upgrade the inherited knowledge (Figure 11).

Figure 11. Technological upgrading: the method for crystallization of karshif within special wooden grids (drawings courtesy of the following authors: Calvano S., Loconte P., Pizzolante S., Ricupero P. and Vitulli A.).
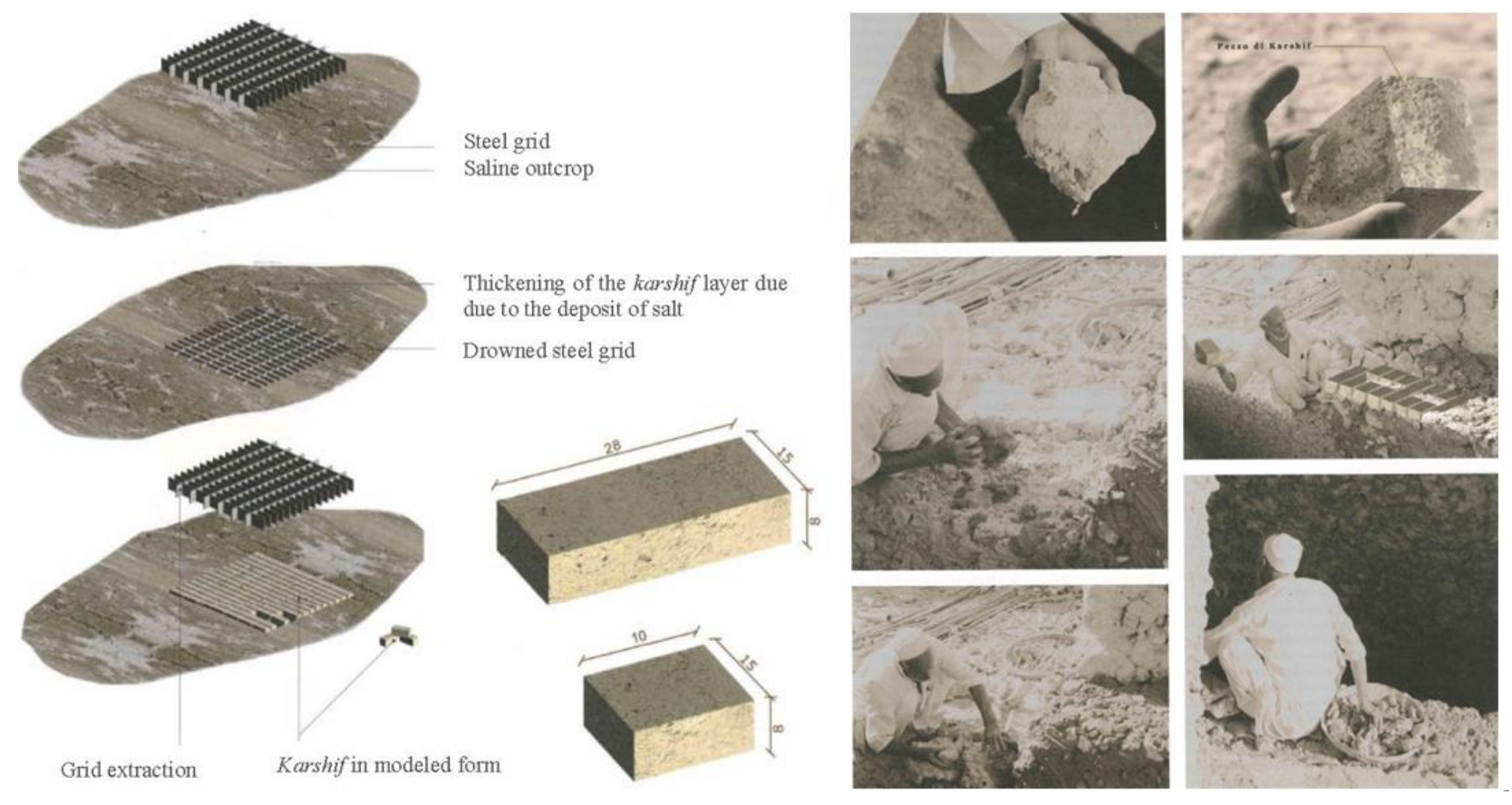
The urban regeneration of Siwa Oasis did not refer to standardized and expensive technological equipment, but rather to those resources (material, social, cultural and economic) that the oasis still offers today. Essentially, the upgrades were aimed at simplifying the building methods and encouraging the possibility of generating a new productive activity through reduced forms of aggression within the environment. It is from this perspective that the development of an innovative method for the crystallization of the karshif, the use of tilaght mortar and the two-layered walls (with an external part made of karshif and an internal part made of tobe) must be interpreted.

To summarize, what emerges from the description of the Siwa Oasis project is that most of the design choices were gleaned from data acquired during a preliminary cognitive evaluation. In fact, through a meticulous analysis of the existing built environment, the designers have, first, recognized the "actuality of traditional knowledge" [10] and, then, transformed that knowledge through an authentic sustainable upgrading.

\section{Conclusions}

On the one hand, this essay refuses the idea of sustainable research merely designed to optimize a building's energetic performances through the evaluation of numerical data. On the other hand, it is an invitation to everyone who accepts the challenge to create sustainable design projects. The invitation is to search for sustainable strategies within a repository of anthropic data stratified within specific cultural areas. In other words, the idea is to recover the concept of "type" as a synthetic concept of transformations that have led to a codified building language [11]. Once this language is recognized and critically interpreted, sustainable research can address socio-cultural needs while expressing a place's building character.

It is unrealistic to entrust terms, like zero-energy development, bioclimatic architecture, eco-buildings and low carbon footprint, with the responsibility of solving the environmental agreement between man and nature. Moreover, if not accompanied by a humble reading exercise of the already existing built reality, such a linguistic phenomenon will attract only those who have shed the weight of tradition from their shoulders and who consider the challenge of sustainability as a pretext to entirely re-write the history of architecture.

\section{Conflicts of Interest}

The author declares no conflict of interest.

\section{References}

1. Caniggia, G.; Maffei, G.L. Architectural Composition and Building Typology: Interpreting Basic Building; Alinea Editrice srl: Firenze, Italy, 2001.

2. Magnaghi, A. Il progetto locale (in Italian); Bollati Boringhieri Editore: Torino, Italy, 2010.

3. Maretto, M. Ecocities. Il progetto urbano tra morfologia e sostenibilità (in Italian); Franco Angeli: Roma, Italy, 2012,

4. Koolhaas, R. Junkspace (in Italian); Quodlibet: Macerata, Italy, 2001.

5. Choay, F. L'allégorie du patrimoine (in Italian); Edition du Seuil: Paris, France, 1999. 
6. Bauman, Z. Modernità Liquida (in Italian); Laterza: Bari, Italy, 2002.

7. Trombetta, C. L'attualità del pensiero di Hassan Fathy (in Italian); Rubettino Editore: Soveria Mannelli, Catanzaro, Italy, 2002.

8. Giuffrè, R. Disegno per una tecnologia dell'ambiente (in Italian); Officina Edizioni: Roma, Italy, 1984.

9. Petruccioli, A.; Montalbano, C. Siwa Oasis, Actions for a Sustainable Development (in Italian); Tipografia Grafica\&Stampa (ICAR): Altamura, Bari, Italy, 2011.

10. Laureano, P. Attualità delle conoscenze tradizionali. In I Paesaggi della Tradizione (in Italian); Petruccioli, A., Stella, M., Eds.; Uniongrafica Corcelli Editrice: Bari, Italy, 2001; Volume 1, pp. 85-102.

11. Petruccioli, A. After Amnesia. Learning from the Islamic Mediterranean Urban Fabric (in Italian); Tipografia Grafica\&Stampa (ICAR): Altamura, Bari, Italy, 2007.

(C) 2014 by the authors; licensee MDPI, Basel, Switzerland. This article is an open access article distributed under the terms and conditions of the Creative Commons Attribution license (http://creativecommons.org/licenses/by/3.0/). 